\title{
Dye Sensitized Solar Cell (DSSC) Efficiency Derived from Natural Source
}

\author{
Muhammad Fajri Maulana, Elvan Yuniarti*, Ai Nurlaela, and Sitti Ahmiatri Saptari \\ Department of Physics, UIN Syarif Hidayatullah Jakarta, Banten 15412, Indonesia
}

\begin{abstract}
Dye Sensitized Solar Cell (DSSC) with natural dye from Leunca fruit (Solanum Nigrym L) and Jamblang fruit (Syzygium Cumini L) extract as sensitizer has been created. This DSSC is composed of $\mathrm{ZnO}$ doping $\mathrm{TiO}_{2}$ using milling tool for 30 minutes which would be used as photoelectrodes. This study used two natural dyes which are Leunca and Jamblang fruit. The characterizations were performed to examine crystal structure of $\mathrm{ZnO}-\mathrm{TiO}_{2}$ with $\mathrm{XRD}$, to measure $\mathrm{ZnO}-\mathrm{TiO}_{2}$ particle size with $\mathrm{SEM}$, to examine optical properties from the dye using UV-Vis spectrophotometer, and to run an electrical test to find the efficiency from DSSC. The results indicate that the use of Jamblang fruit as sensitizer is better than Leunca fruit. This is because Jamblang fruit extract has light absorption area on the range of $250-800 \mathrm{~nm}$ which is higher absorbance than that of Leunca fruit. In addition, the milling time applied was found to be not long enough to produce semiconductor with smaller crystal size. The electrical test result shows Jamblang fruit based DSSC performance is better than Leunca fruit. The maximum power output values are $4.01 \times 10^{-8}$ Watt with the efficiency of $22.57 \times 10^{-4}$ $\%$ and $2.16 \times 10^{-7}$ Watt with efficiency of $6.02 \times 10^{-4} \%$ when radiated with Halogen lamp and sunlight, respectively. Aside from the fact that the preparation technique is relatively easy, natural dye material can be found abundantly in nature and its price is also cheap, hence this study is very promising. However, several changes are needed to gain better results. The brief of this research is to develop alternative energy from solar energy, so that its use can be maximized as environmentally-friendly energy source.
\end{abstract}

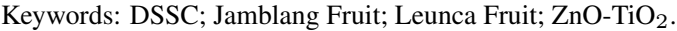

*Corresponding author: elvan.yuniarti@uinjkt.ac.id

Article history: Received 6 July 2021, Accepted 9 September 2021, Published October 2021 http://dx.doi.org/10.12962/j24604682.v17i3.9616

2460-4682 @Departemen Fisika, FSAD-ITS

\section{INTRODUCTION}

Nowadays people are very dependent on electrical energy in performing every activity. However due to the large number of human needs, resources demand is also increasing, but the availability is very limited. Therefore, currently there are many alternatives that can help human in energy that have been developed. The utilization of sun energy is one of the alternatives that has been developed. Solar energy emitted from the sun, received by the earth only $69 \%$ from the total energy emitted. Meanwhile, solar energy supply absorbed by the Earths surface reaches $3 \times 10^{24} \mathrm{~J}$ every year, this is equals to $2 \times 10^{17}$ Watt, or can be said as the total energy is equals to 10,000 times of energy consumed currently in the whole world [1]. Thus, solar energy has the chance in its development as an alternative energy in the future.

One of the development of solar energy is Dye-Sensitized Solar Cell (DSSC) which is one kind of the solar cells developed by Prof. Gretzel and Brian O'Regan in 1991 [2]. DSSC can change light into electrical energy based on sensitization of wide band gap semiconductor materials [3]. DSSC gathers global attention because of the cheap and easy production. Silicone based solar cell had been developed before. The difference between DSSC with silicon solar cell is charge separation and light absorption performed separately. Light absorption performed with coloring molecule while charge sep- aration performed with nanocrystal semiconductor materials [4]. Inside DSSC, there are several important components, including a pair of electrodes (counter and working electrode), electrolytes, and coloring solution [5].

Particle size from semiconductor material affects efficiency of DSSC. This is because the smaller the particle size, the wider surface area of semiconductor layered on TCO glass is. Therefore, it would increase absorbed dyes and electrons that have been through excitation.

Based on several previous studies, this study will make DSSC with photoanode pieces layered by $\mathrm{TiO}_{2}$ semiconductor along with $\mathrm{ZnO}$. Although $\mathrm{TiO}_{2}$ is more expensive than $\mathrm{ZnO}$, but the bandgap from $\mathrm{TiO}_{2}$ is good enough for DSSS. By employing $\mathrm{TiO}_{2}$ along with $\mathrm{ZnO}$, we expect that the bandgap is not too wide to obtain good photocatalysts effect. The composition that would be used for $\mathrm{ZnO}: \mathrm{TiO}_{2}$ in this study is 20\%:80\%. This refers to previous study where the best efficiency was found at $20 \%: 80 \%$ ratio of $\mathrm{ZnO}^{\mathrm{TiO}} \mathrm{Ti}_{2}$ with $0.277 \%$ efficiency [6].

At first, both semiconductor materials are combined using milling technique with High Energy Milling (HEM) to obtain nanocrystal structure with wider band gap so that the electron mobility would be more free. This semiconductor material will also be tested by us with XRD and SEM to view the phase from the material, crystal structure, and chemical composition. Meanwhile, the electrode counter part would 


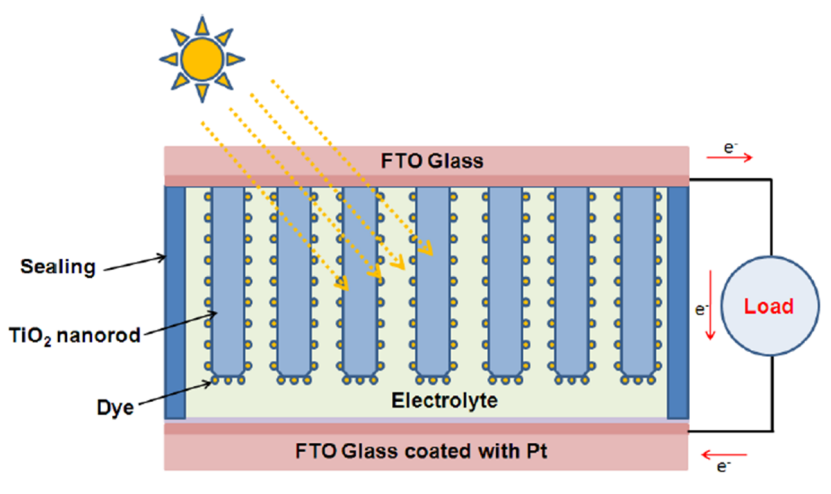

FIG. 1: DSSC structure and work principle [5].
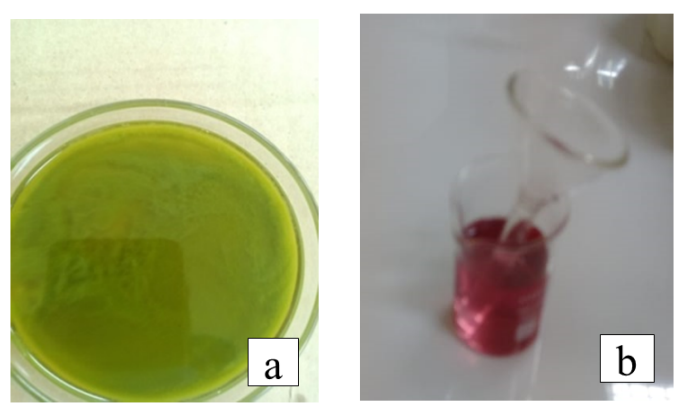

FIG. 2: Finished dye product of (a) Leunca Fruit and (b) Jamblang Fruit.

be made from candle soot. As this study employs natural material-based dye, thus it is expected to generate environmentally friendly energy.

Materials that would be used for natural dye in this study are Leunca and Jamblang fruit. The reasons to use these materials are because their chlorophyl composition. Moreover, to the best of our knowledge there are not so many DSSC studies using natural dye with basic ingredients such as Jamblang and Leunca fruit in past. This study is expected to give an insight of the efficiency of Jamblang and Leunca fruit based sensitizer on DSSC. Here, their dye would be used to prepare sensitizer of DSSC. On the previous study conducted by M. Gretzel using ruthenium complex material resulting $11-12 \%$ efficiency [7]. However, this material supply in nature is extremely rare and not environmentally friendly. So, the alternative dye using material from nature, like fruits, vegetables, flowers, and leaves are sought.

The dye is the characterized with UV Vis spectrophotometer to measure wavelength and absorption value, and also to estimate gap energy value of the dye. After DSSC successfully assembled and circuit is arranged, several characterizations are carried out, namely voltage and current testing. The $\mathrm{ZnO}-\mathrm{TiO}_{2}$ paste is prepared using milling technique which is expected to create better efficiency when applied into DSSC compared to $\mathrm{ZnO}-\mathrm{TiO}_{2}$ without milling technique reported in previous study [6]. The novelty here is creating DSSC using dye materials from Jamblang fruit and Leunca fruit with photoelectrode materials using $\mathrm{ZnO}-\mathrm{TiO}_{2}$ made from milling technique.

\section{METHOD}

\section{A. Tools and Materials}

In this study, tools used were beaker glass, glass stirring rod, petri dish, measuring cup, magnetic stirrer, spatula, mortar, digital balance, blender, weighing paper, filter papers, oven, measuring and dropping pipettes, digital multimeter, scotch tape, paper clips, scissor, cutter, halogen lamp $1000 \mathrm{~W}$, potentiometer, luxmeter, hygrometer, x-ray diffraction, UVVis spectrophotometer, and spex shaker mills.

Meanwhile materials used were Indium Tin Oxide (ITO) glass, $\mathrm{TiO}_{2}$ (Merck), ZnO (Merck), PolyEtilen Glicol liquid (PEG) 400 (Merck), Poly Venil Aldehide (PVA) 500 (Merck), metanol $\left(\mathrm{CH}_{3} \mathrm{OH}\right)$ (Merck), Alcohol 96\%, Potassium Iodida (KI) (Merck), iodium (Merck), aquades, Jamblang fruit, and Leunca fruit.

\section{B. Preparation of Natural Dye Sensitizers}

Fresh Jamblang and Leunca fruit were extracted by mashing it first using blender into $40 \mathrm{ml}$ aquades which is then filter using filter paper. The resulted extract of Leunca fruit is then added with $100 \mathrm{ml}$ methanol and that of Jamblang fruit with $100 \mathrm{ml}$ aquades. The resulted dye prepared from Leunca and Jamblang fruit can be seen in Fig. 2.

\section{Preparation of $\mathrm{ZnO}-\mathrm{TiO}_{2}$ Paste}

In $\mathrm{ZnO}-\mathrm{TiO}_{2}$ paste production, there are two materials that needed to be made, which are $\mathrm{ZnO}-\mathrm{TiO}_{2}$ powder and gel solution. $\mathrm{ZnO}$ and $\mathrm{TiO}_{2}$ were milled at first with composition ratio of $80 \%(\mathrm{ZnO}): 20 \%\left(\mathrm{TiO}_{2}\right)$ for 30 minutes. This composition is based on that acquire the best efficiency in previous study [6]. Furthermore, gel production from the mixture of $0.4 \mathrm{gr}$ PVA and $8 \mathrm{ml}$ aquades was prepared using magnetic stirrer for an hour, with $80^{\circ} \mathrm{C}$ temperature and at the speed of 300 rpm. After $\mathrm{ZnO}-\mathrm{TiO}_{2}$ powder was already milled and gel had been made, both of those materials were mixed using mortar for 30 minutes until it turned into paste.

\section{Preparation of Electrode and Counter Electrode}

ITO glass is cut with $2 \mathrm{~cm} \times 2 \mathrm{~cm}$ size for each electrode. The side part of ITO glass is attached with scotch tape, so only the center part of glass with $1.5 \mathrm{~cm} \times 1 \mathrm{~cm}$ size remains. The center part of ITO coated with $\mathrm{ZnO}-\mathrm{TiO}_{2}$ using doctor bladding method, then heated inside an oven for 15 minutes (See Fig. 3a). Next, the electrode is soaked in a dye for 24 hours. Meanwhile for the counter electrode, the center part of ITO glass is coated with carbon made of candle flame, where 

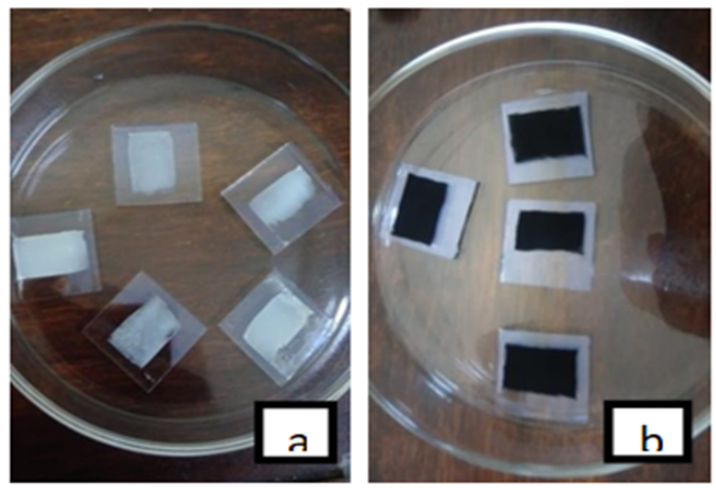

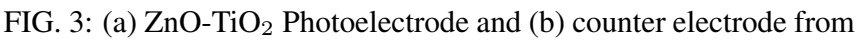
the candle flame.
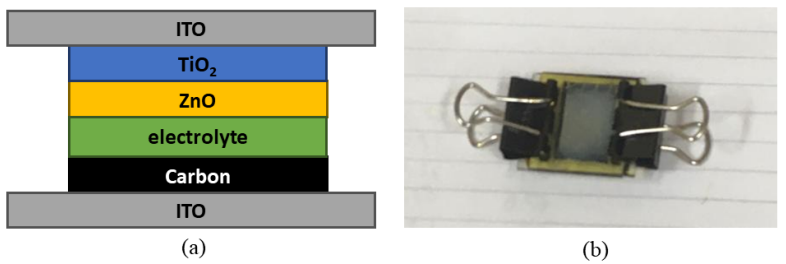

FIG. 4: (a) DSSC Structure and (b) DSSC prototype.

the ITO glass is burned until black color appeared on the ITO glass.

\section{E. DSSC Assembling}

Electrolyte solution must be made first before DSSC assembly. Electrolyte is made with $8.3 \mathrm{gr} \mathrm{KI}, 1.26$ gr iodine, and 100 $\mathrm{ml}$ PEG mixture [9], which were mixed using magnetic stirrer for 30 minutes with $80^{\circ} \mathrm{C}$ temperature and at the speed of 300 rpm. Electrolyte solution that had been made was then stored in glass bottle coated with aluminum foil in room temperature to prevent it exposed to light.

DSSC is composed of several components with a structure presented in Fig. 4. The first part is $\mathrm{ZnO}-\mathrm{TiO}_{2}$ photoelectrode which previously soaked in dye, then electrolyte solution for $2 \mathrm{ml}$ was added. After that, the counter electrode is placed above the photoelectrode where the carbon coated part must be attached to the photoelectrode. After being assembled like a sandwich, both electrodes are clamped using paper clip on left and right sides, as shown in Fig. 4.

\section{F. Characterization and Measurement}

To know the performance of DSSC, several tests were conducted. Absorption spectrum from dye is examined using UV-Vis spectrophotometer. Crystal structure and crystal size from $\mathrm{ZnO}-\mathrm{TiO}_{2}$ photoelectrode layer examined with X-Ray

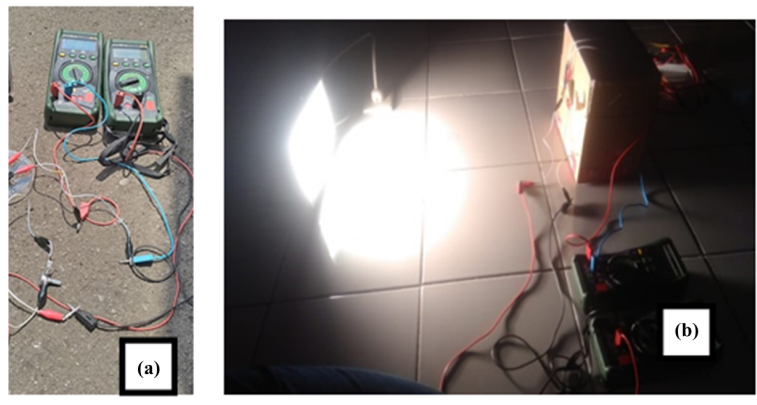

FIG. 5: DSSC electric test on (a) sunlight and (b) halogen lamp.

Diffraction (XRD), and the morphology observed with Scanning Electron Microscope (SEM). DSSC efficiency is measured with different light sources, which are 1000 Watt halogen lamp and sunlight. The DSSC efficiency is estimated using Eq. 1 [9].

$$
\eta=\frac{P_{\max }}{P_{\text {light }} \cdot A} \times 100
$$

Where $P_{\max }$ is the maximum power output obtained from multiplication result of maximum current output and maximum voltage output. Then $A$ is an area surface of DSSC coated photoelectrode part and $P_{\text {light }} \mathrm{t}$ is sunlight power measured using luxmeter, where 1 lux value equals to 0.0079 $\mathrm{W} / \mathrm{m}^{2}[8]$.

Electricity test used six variations of resistors, which are 0 , $2,5,10,50$, and $250 \mathrm{~K} \Omega$. In the test with halogen lamps, the intensity of light used is 1,500 lux, while in sunlight the intensity of light used is in the range of 15,000 - 150,000 lux because sunlight is polychromatic so it is difficult to determine the intensity of light used.

In addition to experimentally calculated efficiency, this study also calculates theoretical efficiency which will later be compared between those two values. The equations used for theoretical calculations are expressed in Eq. 2 and Eq. 3.

$$
\begin{gathered}
I=I_{L}-\frac{V-R_{s} I}{R_{s h}}-I_{0}\left\{\exp \left[\frac{q\left(V-R_{s} I\right)}{n k T}\right]-1\right\} \\
I_{0}=\frac{I_{L}}{\exp \left(\frac{V_{O C} q}{n k T}-1\right)}
\end{gathered}
$$

Where $I$ is the current that you want to find the value, $V$ is the voltage obtained from the test results, $I_{L}$ is the current strength whose value is equal to $I_{s c}, I_{o}$ is the saturation current of the diode, $R_{s}$ is the series resistance, $R_{s h}$ is the parallel resistance, $q$ is the electron charge $\left(1.602 \times 10^{-19} \mathrm{C}\right), k$ is the Boltzmann constant $\left(1.38 \times 10^{-23} \mathrm{~J} / \mathrm{K}\right), T$ is the DSSC temperature during the test, and $n$ is the diode ideality factor [10].

The circuit of electricity test on DSSC can be seen on Fig. 5 , but for the theoretical calculation here using mathematical model with circuit equivalent to one diode [8]. The use of mathematical modeling like this is due to the standard DSSC circuit using a diode equivalent circuit [10]. 


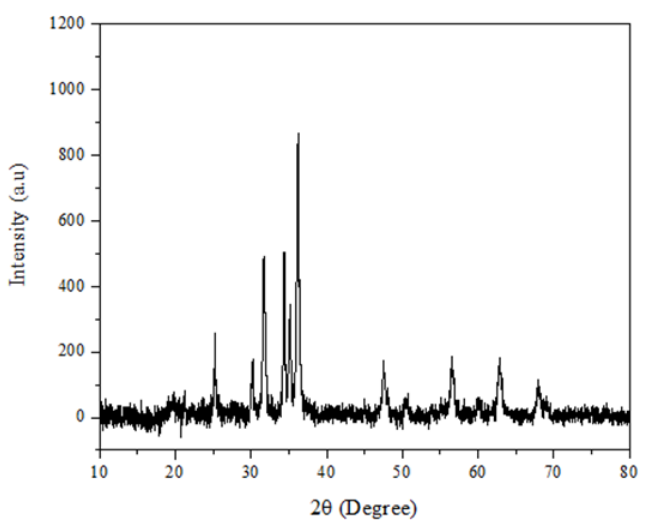

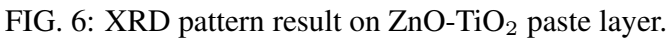

TABLE I: XRD characterization data on two representative peaks of $\mathrm{ZnO}$ and $\mathrm{TiO}_{2}$ phase

\begin{tabular}{lllc}
\hline Phase & $2 \theta\left(^{\circ}\right)$ & FWHM (rad) & Particle size $(\mathrm{nm})$ \\
\hline $\mathrm{TiO}_{2}$ & 25.27 & 0.004915844 & 30.178 \\
$\mathrm{TiO}_{2}$ & 62.80 & 0.008518122 & 19.906 \\
$\mathrm{ZnO}$ & 34.38 & 0.005348467 & 28.330 \\
$\mathrm{ZnO}$ & 36.21 & 0.006430022 & 23.685 \\
\hline
\end{tabular}

\section{RESULTS AND DISCUSSION}

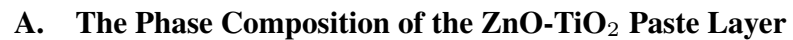

Analysis of XRD data using General Structure Analysis System (GSAS) and Match II software shows that ${\mathrm{ZnO}-\mathrm{TiO}_{2}}_{2}$ paste have three phases, which are $\mathrm{ZnO}, \mathrm{TiO}_{2}$, and $\mathrm{In}_{4} \mathrm{O}_{12} \mathrm{Sn}_{3}$ with the composition of $83.5 \%, 11.4 \%$, and $5.1 \%$, respectively. $\mathrm{ZnO}$ composition is higher than $\mathrm{TiO}_{2}$ because the ratio of $\mathrm{ZnO}: \mathrm{TiO}_{2}$ is $80 \%: 20 \%$ or equal to $2.22 \mathrm{gr} \mathrm{ZnO}$ and $0.56 \mathrm{gr}$ $\mathrm{TiO}_{2}$. The present of $\mathrm{In}_{4} \mathrm{O}_{12} \mathrm{Sn}_{3}$ is because the sample being tested is in the form of a paste coated on ITO glass. Thus the peaks of ITO glass is detected by XRD. The resulted XRD data that was processed using GSAS can be seen in Fig. 6.

The $\mathrm{ZnO}$ crystal is detected around diffraction angles of $31.1725,34.3824,36.2100,47.5231$, and $67.9515^{\circ}$. Meanwhile for $\mathrm{TiO}_{2}$ crystal is detected around diffraction angles of 25.2670 and 62.7978 . Crystal structure of $\mathrm{ZnO}$ and $\mathrm{TiO}_{2}$ was found to be hexagonal and tetragonal, respectively.

The crystal size can be calculated using the Scherrer equation as presented in Eq. 4 [11].

$$
D=\frac{0.94 \lambda}{\mathrm{FWHM} \cos \theta}
$$

Where $D$ is crystal size (nm), FWHM is highest peak half width size (radian), $\lambda$ is $\mathrm{Cu} K_{\alpha}$ wavelength with the value of $0.154 \mathrm{~nm}$, and $\theta$ is the used diffraction angle (radian).

Crystal size greatly affects DSSC performance, because the smaller the crystal size the more dye attached to the semiconductor material, and as the result it will absorb more photon. Compared to several previous studies, the crystal size in this

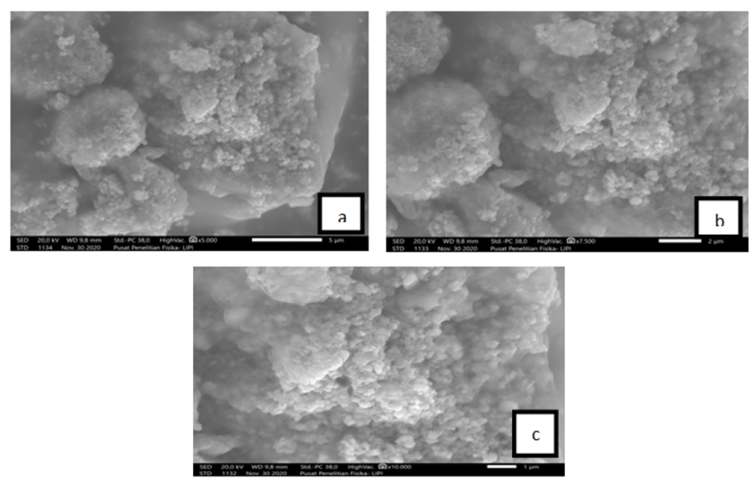

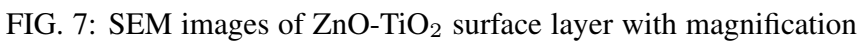
of (a) $5,000 \times$, (b) $7,500 \times$, and (c) $10,000 \times$.

study is still big. In the study of Aksoy et al, the $\mathrm{ZnO}$ doped $\mathrm{Li}$ had a crystal size of 5-7 nm [5]. Another study by Kumila et al with nanosized $\mathrm{TiO}_{2}$, the crystal size was reported to be $10.5 \mathrm{~nm}$ [12]. The milling technique was carried out to get a smaller crystal size, but in this study the crystal size was small enough. This is because the milling time is only 30 minutes. In a study conducted by Puspa et al, the effect of milling time on crystal size was that the longer the milling time the smaller the crystal size [13].

\section{B. Morphology of the ${\mathrm{ZnO}-\mathrm{TiO}_{2}}_{2}$ Paste Layer}

Thin layer on DSSC has an important role in DSSC circuit, because in this part is where the light absorption occurred which later would be converted into electrical energy. The morphology of this material greatly affects how DSSC works later. Various kinds of morphology on this thin layer would affect the performance. Image result from SEM on $\mathrm{ZnO}-\mathrm{TiO}_{2}$ paste layer with the magnification of $5,000 \times, 7,500 \times$, and $10,000 \times$ can be seen in Fig. 7 .

If we see Fig. 10, the SEM images of $\mathrm{ZnO}-\mathrm{TiO}_{2}$ layer have the form of porous spherical particles. In addition, in this thin layer there is a lot of agglomeration due to the preparation process of semiconductor paste using a binder in the form of a gel from a mixture of PVA and aquades. The amount of binder composition affects the amount of agglomeration formed [14]. As the result of this agglomeration, the efficiency produced by DSSC is not good enough because of the resistance to electron mobility. Therefore, the value of the voltage and current density becomes smaller due to this agglomeration [15].

\section{The Absorption Wavelength of Jamblang and Leunca Dye}

The absorbance spectrum can be examined with UV Vis spectrophotometer on the range of 250-800 nm wavelength for both Leunca and Jamblang fruit. The peak was obtained at a wavelength of $285 \mathrm{~nm}$ for Leunca fruit and $530 \mathrm{~nm}$ for Jamblang fruit, while the highest absorbance value for Leunca 


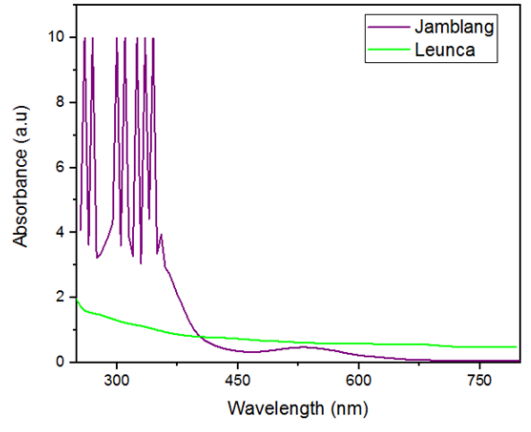

FIG. 8: UV Vis test result chart for Leunca fruit and Jamblang fruit.
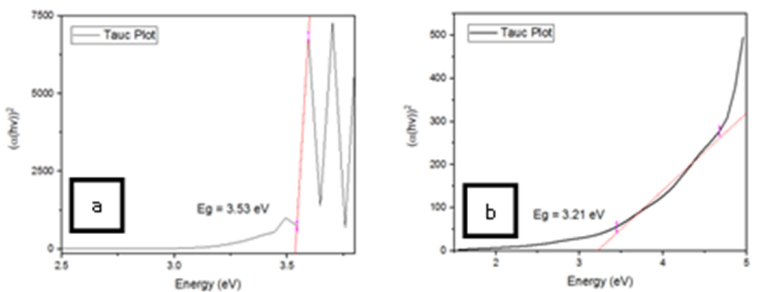

FIG. 9: Tauc Plot Graph for Jamblang fruit (a) and Leunca fruit (b).

fruit is 1.94 a.u and for Jamblang fruit is 10.00 a.u. Based on absorption wavelength, Leunca fruit dye can absorb more light on the range of UV spectrum with quite high absorbance value, while Jamblang fruit dye can absorb light on visible light spectrum. Both of these materials have a fairly wide wavelength, so they can absorb a wide range of light spectrum. The results of the UV-Vis spectrophotometer can be seen in Fig. 8.

The energy gap of the two dyes can be determined using the Tauc plot method as represented in Eq. 5.

$$
\begin{gathered}
\frac{(\alpha h c)^{2}}{\lambda}=K\left(\frac{h c}{\lambda}-E_{g}\right) \\
\alpha=\frac{2.303 A}{I}
\end{gathered}
$$

Where $h$ is Plancks constant $\left(6.63 \times 10^{-34} \mathrm{~J} . \mathrm{s}\right), \alpha$ is absorbance coefficient, $A$ is absorbance, $l$ is the thickness of cuvette used, $K$ is the comparison constant, $c$ is the speed of light $\left(3 \times 10^{8} \mathrm{~m} / \mathrm{s}^{2}\right), \lambda$ is the wavelength, and $E_{g}$ is energy gap [16].

The results of the energy gap calculation using the Tauc plot method can be seen in Fig. 9. There is one point where the energy gap value is taken, but the data used is the interval of the energy gap value at a wavelength of $250-800 \mathrm{~nm}$ as shown in Table 2.

The utilization of dye as a sensitizer must have small energy gap than that of the semiconductor material. This is because charge separation happened on DSSC. When emitted photon energy from the light source absorbed by dye, the electrons in
TABLE II: The UV-Vis measurement results of Jamblang and Leunca Dye

\begin{tabular}{lll}
\hline Dye & Wavelength $(\mathrm{nm})$ & Energy Gap $(\mathrm{eV})$ \\
\hline Jamblang & $250-800$ & $4.96-1.55$ \\
Leunca & $250-800$ & $4.95-1.54$ \\
\hline
\end{tabular}

dye would go through excitation from HOMO (Highest Occupied Molecular Orbital) condition to LUMO (Lowest Unoccupied Molecular Orbital) which then electron would be transferred to conduction band in semiconductor [5].

The semiconductor material used is $\mathrm{ZnO}-\mathrm{TiO}_{2}$, where energy gap from both of those materials is not that much of different, which is $3.2 \mathrm{eV}$ [17]. Characteristic from bandgap greatly affects the value of the absorption coefficient of light and the rate of electron-hole recombination [18].

Based on Table 2 and Fig. 9, one can see that the energy gap of Jamblang and Leunca fruit are not too different and the value is a little bit bigger than those of $\mathrm{ZnO}$ and $\mathrm{TiO}_{2}$. This energy gap value causes the DSSC to be less than optimal to generate electricity. The absorbance of Leunca dye is highest at UV light wavelengths, while Jamblang fruit dye is found in visible light. So that, when radiated with sunlight, Jamblang dye absorbs more light.

\section{DSSC Performance}

In this study, the DSSC efficiency was calculated experimentally with Eq. 1 and theoretically with Eqs. 2 and 3. Comparison of the obtained results can be seen in Table 3 .

By looking at the UV-Vis data and electrical testing obtained, the best dye used is a dye made from Jamblang fruit. Jamblang dye has wavelength absorption from UV to visible light. So that if it is used as a sensitizer in a solar cell, it will be better than Leunca dye. Moreover, the gap energy of Jamblang dye is smaller than Leunca fruit. The photoelectrode that had been made using $\mathrm{ZnO}$ doped by $\mathrm{TiO}_{2}$ produces a fairly good layer with a porous spherical morphology. From the XRD results the photoelectrode crystal size is still not small enough because the milling time used is only $30 \mathrm{~min}$ utes.

However, there are still many shortcomings in terms of performance. Where the output voltage and current from the DSSC is still very small when compared to other similar studies. There are several factors that make the efficiency of this DSSC small. First, the liquid electrolyte is volatile and leaks. In the electrolyte gel made without using chloroform, only polyethylene glycol (PEG) was used. Whereas in a study conducted by Kumila et al using gel electrolytes that were not easy to evaporate and leak [12]. The second reason is that there is agglomeration in the photoelectrode layer which results in resistance to electron mobility. And the third, the milling time is not long enough. 
TABLE III: DSSC efficiency calculated result experimentally and theoretically

\begin{tabular}{lllllll}
\hline \multirow{2}{*}{ Dye } & \multirow{2}{*}{ Illumination } & \multirow{2}{*}{ Lux } & \multirow{2}{*}{$\mathrm{V}_{O C}(\mathrm{mV})$} & \multirow{2}{*}{$\mathrm{I}_{S C}(\mu \mathrm{A})$} & \multicolumn{2}{c}{ Efficiency $\left(\times 10^{-4} \%\right)$} \\
\cline { 5 - 7 } Leunca & Sun light & 11700 & 167.76 & 1.24 & 8.80 & 8.60 \\
Leunca & Halogen lamp & 1500 & 13.25 & 1.45 & 0.73 & 2.40 \\
Jamblang & Sun light & 30300 & 142.02 & 5.08 & 11.24 & 6.02 \\
Jamblang & Halogen lamp & 1500 & 39.46 & 2.16 & 18.91 & 11.57 \\
\hline
\end{tabular}

\section{SUMMARY}

Dye Sensitized Solar Cell (DSSC) using photoelectrode from $\mathrm{ZnO}-\mathrm{TiO}_{2}$ mixture with sensitizer materials from Jamblang and Leunca fruit was successfully fabricated. Both Jamblang and Leunca fruit can be used as sensitizer on DSSC. Better DSSC performance was found when the sensitizer is prepared from Jamblang fruit. As Jamblang dye has bigger absorbance along with smaller gap energy than that of Leunca dye. Even though the DSSC in this study had been made successfully, it turns out the efficiency is still relatively small and need further research to improve the deficiencies, such as by increasing the milling time, preventing the agglomeration of the photoelectrode layer and the leakage of the electrolyte gel.

\section{Acknowledgment}

S.A. Ahmiatri and E.Y acknowledge Funding From UIN Syarif Hidayatullah Jakarta. We acknowledge Suport of Puslitpen UIN Syarif Hidayatullah Jakarta and PLT UIN Syarif Hidayatullah Jakarta.
[1] S. Marthua, R. Nadeak, and D. Susanti, "Variasi Temperatur dan Waktu Tahan Kalsinasi ( DSSC ) dengan Dye dari Ekstrak Buah Naga," Jurnal Teknik ITS, vol. 1, pp. 27, 2012.

[2] M. Grätzel, "Dye-sensitized solar cells," J. Photochem. Photobiol. C Photochem. Rev., vol. 4, no. 2, pp. 145153, 2003.

[3] D. S. Boning and O. Ouma, "Chapter 4 Modeling and Simulation," Semicond. Semimetals, vol. 63, no. C, pp. 89137, 1999.

[4] A. Fitria, A. Amri, A. Fadli, and B. O. Regan, "Pembuatan Prototip Dye Sensitized Solar Cell ( DSSC ) Menggunakan Dye Ekstrak Buah Senduduk ( Melastoma Malabathricum L ) dengan Variasi Fraksi Pelarut dan Lama Perendaman Coating $\mathrm{TiO}_{2}$," Jurnal Online Mahasiswa Fakultas Teknik Universitas Riau, vol. 3, pp. 19, 2016.

[5] S. Aksoy, O. Polat, K. Gorgun, Y. Caglar, and M. Caglar, ”Li doped ZnO based DSSC: Characterization and preparation of nanopowders and electrical performance of its DSSC," Phys. E Low-Dimensional Syst. Nanostructures, vol. 121, no. April, p. 114127, 2020.

[6] H. Tong, M. Inada, Y. Tanaka, and N. Enomoto, "Dye Sensitized Solar Cells based on $\mathrm{ZnO}$ Nanorod/TiO 2 Nanoparticle Composite Films," Mat. Sci. Forum, vol. 724, pp. 397403, 2012.

[7] M. Grätzel, "Dye-sensitized solid-state heterojunction solar cells," MRS Bull., vol. 30, no. 1, pp. 2327, 2005.

[8] N. A. Siddiq, "Fabrikasi Dye-Sensitized Solar Cell (DSSC) Berstruktur Bilayer Anatase $\mathrm{TiO}_{2}$ Dalam Rangkaian Seri dan Paralel," Thesis, Institut Teknologi Sepuluh Nopember, Surabaya, Indonesia, 2015.

[9] M. C. Misbachudin, F. S. Rondonuwu, and A. Sutresno, "Pengaruh pH Larutan Antosianin Strawberry dalam Prototipe Dye Sensitized Solar Cell (DSSC)," J. Fis. dan Apl., vol. 10, no. 2, pp. 57-62, 2014.

[10] M. Belarbi, A. Benyoucef, and B. Benyoucef, "Study of Equivalent Circuit of a Dye Sensitized Solar Cell," Advanced Energy: An International Journal (AEIJ), vol. 1, no. 2, pp. 1-8, 2014.
[11] M. Rabiei, A. Palevicius, A. Monshi, and S. Nasiri, "Comparing Methods for Calculating Nano Crystal Size of Natural Hydroxyapatite Using X-Ray Diffraction," Nanomaterials, vol. 10, no. 9, 1627, 2020.

[12] B. N. Kumila and G. Prajitno, "The Effect of Gel-Electrolyte on Dye Sensitized Solar Cell (DSSC) Prototype based on Nanosized- $\mathrm{TiO}_{2}$ Using Mangosteen Pericarp as Absorber," $J$. Nat. Sci. Math. Res., vol. 3, no. 1, p. 186, 2017.

[13] N. Puspa, N. A. Silviyanti, G. Yudoyono, G. Prajitno, A. Rubiyanto, and E. Endarko, "Pengaruh Ketebalan Lapisan $\mathrm{TiO}_{2}$ terhadap Performasi Dye Sensitized Solar Cells," J. Fis. dan Apl., vol. 14, no. 1, p. 12, 2018.

[14] K. H. Ko, Y. C. Lee, and Y. J. Jung, ”Enhanced efficiency of dye- sensitized $\mathrm{TiO}_{2}$ solar cells (DSSC) by doping of metal ions," J. Colloid Interface Sci., vol. 283, no. 2, pp. 482487, 2005.

[15] H. A. Deepa, G. M. Madhu, and V. Venkatesham, "Performance evaluation of DSSCs fabricated employing $\mathrm{TiO}_{2}$ and $\mathrm{TiO}_{2}-\mathrm{ZnO}$ nanocomposite as the photoanodes," Materials Today:Proceedings, vol. 46, part. 10, pp. 4579-4586, 2020.

[16] D. J. Satheesh and J. Isac, "Optical Analysis, Urbach and Bandgap Energy of $\mathrm{Mn}_{0.8+x} \mathrm{Zn}_{0.2} \mathrm{Ti}_{x} \mathrm{Fe}_{2-2 x} \mathrm{O}_{4}$ with $x=0.15$ Manganese - Zinc Ferrite system doped with Titanium," International Journal of Science and Research (IJSR), vol. 4, no. 10, pp. 605610, 2015.

[17] J. Tian, J. Wang, J. Dai, X. Wang, and Y. Yin, "N-doped $\mathrm{TiO}_{2} / \mathrm{ZnO}$ composite powder and its photocatalytic performance for degradation of methyl orange," Surf. Coatings Technol., vol. 204, no. 5, pp. 723730, 2009.

[18] E. Yuniarti, "Studi Komputasi Sifat Elektronik dan Sifat Optik Fotoelektroda Titanium Dioksida $\left(\mathrm{TiO}_{2}\right)$ pada Fasa Anatase dan Rutile," Al-Fiziya, vol. II, no. 1, pp. 4048, 2019. 